НЕРУБАЦЬКИЙ В. П., к.т.н., старший викладач, ПЛАХТІЙ О. А., к.т.н., старший викладач,

ГОРДІЕНКО Д. А., магістрант (Український державний університет залізничного транспорту)

\title{
Розробка тривимірної моделі системи «рама візка - тягові електродвигуни» для електровоза ЧС4 за допомогою програмного продукту SolidWorks
}

У статті розглянуто недоліки в існуючій моделі рами візка електровоза ЧС4, пов'язані з ослабленням кронштейнів кріплення, а також технологією монтажу тягових двигунів. Здійснено розробку тривимірної моделі рами візка з двигунами за допомогою програмного продукту SolidWorks. Проведено розрахунок власних частот за допомогою програмного продукту MSC.Patran.

Ключові слова: залізничний транспорт, електровоз, рама візка, кронштейни, додаткова балка, модель.

\begin{abstract}
Вступ
Ритмічна та стійка робота залізничного транспорту багато в чому залежить від надійності тягового рухомого складу та ефективності його використання. Питання надійності роботи електрорухомого складу (ЕРC) безпосередньо залежить від надійності роботи механічної частини локомотива [3]. Одним з основних елементів механічної частини $є$ рама візка. Як i більшість інших елементів механічної частини, вона $є$ нерезервованим вузлом, і внаслідок цього будь-яка ii несправність призводить до виходу 3 ладу одиниці тягового рухомого складу. Тому на сучасному етапі розвитку залізничної галузі необхідним є генерування та впровадження прогресивних рішень при проектуванні рухомого складу XXI сторіччя.
\end{abstract}

\begin{tabular}{l}
\hline Мета дослідження \\
Дослідження спрямовано на вирішення проблем у \\
галузі залізничного транспорту, пов’язаних з \\
ослабленням кронштейнів кріплення тягових двигунів \\
до рами візка, а також технологією монтажу тягових \\
двигунів. Для цього передбачається розробити модель \\
конструкції рами 3 урахуванням вузлів кріплення \\
тягових двигунів і зв’язку їх із самим тяговим \\
двигуном, а також модель модернізованої конструкції і \\
оцінити величини амплітуд коливань і власні частоти. \\
На підставі розрахунків оцінити доцільність \\
упровадження модернізації і якісно оцінити ії \\
результати.
\end{tabular}

\section{Основний матеріал дослідження}

Рама візка $є$ елементом, що замикає на собі всі сили, які виникають у локомотиві. При оцінці міцності рами візка доводиться враховувати напруження, що виникає від статичних навантажень: ваги кузова, тягових двигунів, гальмівного устаткування, розміщеного на ній; від сил тяги; від динамічних сил, що є результатом коливань локомотива у вертикальній площині; від сил, що передаються осями колісних пар у горизонтальній площині при звивистому руху в прямих ділянках колії і при вписуванні в криві; від сил, що виникають у повертальному пристрої i міжвізковому з'єднанні тощо [2].

За наявності досить високого рівня сил, що діють на раму візка, допустимий рівень напруження може бути досягнутий тільки за рахунок підбору відповідних моментів опору складових їі елементів. 3 іншого боку, конструкція має бути по можливості легкою. Останнє випливає як з економічних міркувань, так і з умови дотримання загальної вагової норми локомотива (навантаження на вісь). Необхідність створення легкої і міцної конструкції спонукала проектувальників відмовитися від рам брусків і перейти до зварних рам, складених із порожнистих балок коробчатого перетину [1]. Цей принцип i покладений в основу конструкції рами візка електровозів ЧС4.

Складовими елементами рами (рис. 1) є боковини 1 , шворневий брус 2 , поперечний брус 3 , передня 4 i задня 5 кінцеві балки [4]. 


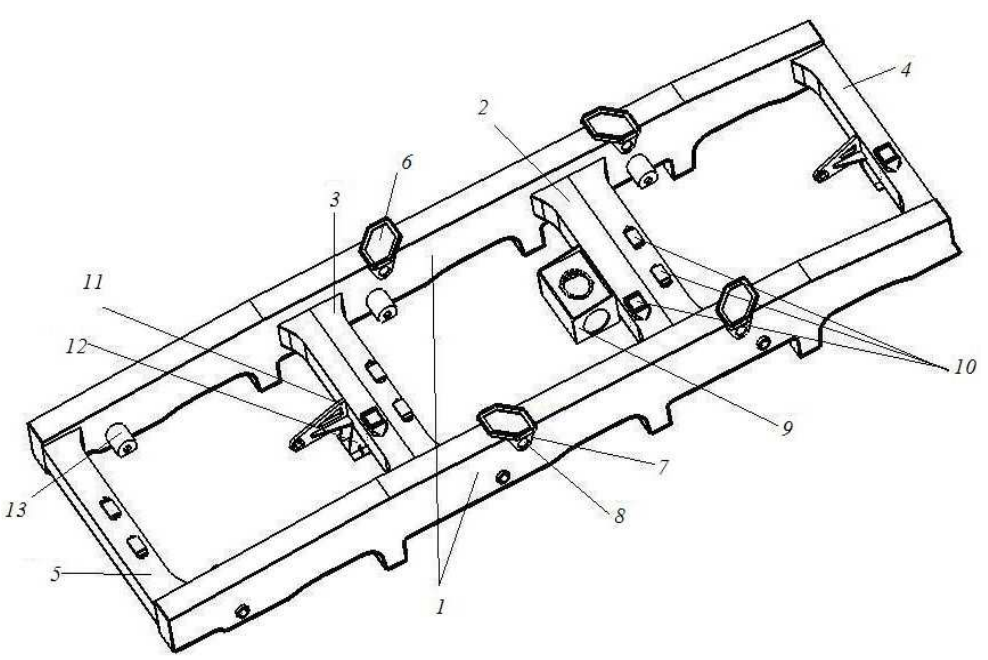

Рис. 1. Рама візка

Шворневий брус 2 розташований між першою i другою або п'ятою і шостою осями. Він є зв' язком між боковинами, місцем розміщення шворневого гнізда 3 повертальним пристроєм, а так само i місцем кріплення першого i другого тягових двигунів i корпусу редуктора привода першої осі. За конструкцією брус також $\epsilon$ порожнистою балкою коробчатого перетину, звареною 3 двох фасонних штампованих елементів. Лита коробка 9 шворневого вузла вварена в середню частину балки. Опори 10 тягових двигунів і плита кріплення редуктора також литі і з'єднані з балками зварюванням. Шворневу балку приварюють до боковин на відстані 105 мм від верхньої і на 140 мм від нижньої горизонтальної площини. Таке з’єднання шворневої балки 3 боковинами має на меті зсув концентратора напруги, яким є місце з'єднання, в зону малої напруги, що виникає при вертикальному вигині боковин. Вказана схема з'єднання 3 боковинами характерна для всіх поперечних балок рами візка електровоза ЧС4. До поперечної і передньої кінцевої балок приварені кронштейни кріплення гальмівних циліндрів 12 i важільної гальмівної системи 11.

На електровозі ЧС4 здійснено опорно-рамну підвіску тягових двигунів [4] (рис. 2). Застосування цього типу підвіски значно (на $25 \div 30 \%$ ) знижує вагу безпружинних частин, що позитивно позначається на контактній міцності рейок.

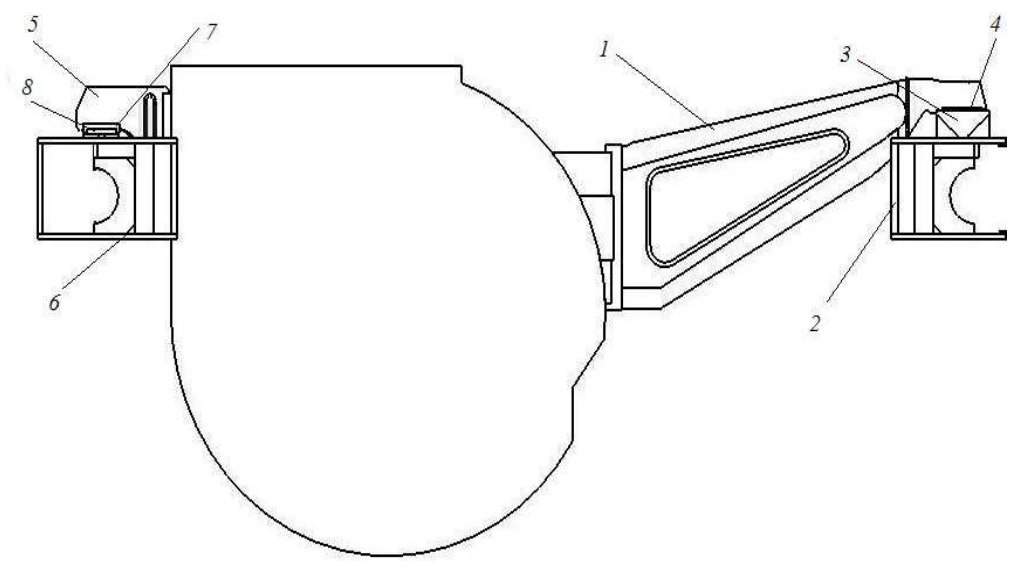

Рис. 2. Підвіска тягового електродвигуна

До кінцевих i поперечних балок кріплять три кронштейни тягових двигунів. 3 боку осі колісної пари до остова тягового електродвигуна за допомогою восьми болтів прикріплений передній кронштейн двигуна 1 , який через опору 3 спирається на поперечну балку 2. На опору 3 передній кронштейн спирається через вставку 4, яка при монтажі потребує високоточної обробки, і затягується двома болтами М30. Цей принцип кріплення має істотний недолік, оскільки при здійсненні ремонтних робіт необхідно 3 високою точністю обробити та підігнати вставку під кронштейн.

Наявність зазорів у кріпленні може призвести до ослаблення болтів, і конструкція стане ненадійною. 
Дві інші точки підвішування електродвигуна розташовані на протилежному боці остова.

Конструктивно кріплення 5 виконані у вигляді двох литих кронштейнів. До остова двигуна кронштейни кріпляться трьома болтами М30. На кінцеву балку 6 кронштейни спираються, так само як і передній кронштейн, через спеціальну опору 8 і вставку 7, що потребує високоточної обробки при монтажі.
Конструкція переднього кронштейна середнього електродвигуна 1 (рис. 3) відрізняється від конструкції кронштейнів переднього 4 i заднього 3 електродвигунів. Передній кронштейн має зігнуту форму. Його не можна виконати прямим через те, що він спирається на шворневу балку 2, в яку вварений шворневий вузол 5 і він не дає змоги виконати кронштейн такої самої форми, як на передньому та задньому електродвигунах.

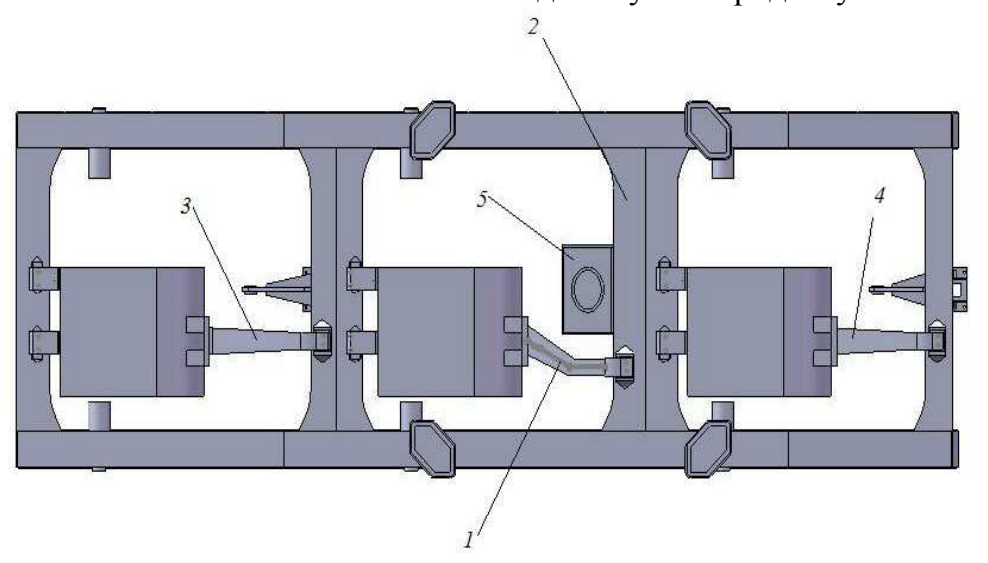

Рис. 3. Рама візка (вигляд зверху)

Моделювання рами візка 3 тяговими електродвигунами було здійснено за допомогою програмного продукту SolidWorks [6]. Програма SolidWorks - це система автоматизованого проектування, що використовує звичний графічний інтерфейс користувача Microsoft Windows. Цей легкий в освоєнні засіб дає змогу інженерампроектувальникам швидко відображати свої ідеї в ескізі, експериментувати з елементами і розмірами, а також створювати моделі і докладні креслення.

Модель SolidWorks складається 3 тривимірної геометрії твердотільних елементів у документах деталей і складань. Креслення створюються 3 моделей або шляхом креслення видів у документі креслення. Зазвичай спочатку накреслюється ескіз, створюється основа, а потім у модель додаються численні елементи. Можна удосконалити проект шляхом додавання, редагування або переупорядковування елементів. Зв'язок між деталями, складаннями i кресленнями гарантує, що зміни, зроблені в одному документі або вигляді, автоматично виконуються в усіх інших документах i виглядах. Креслення або складання можна створювати на будь-якому етапі в процесі проектування.

Тривимірна модель рами візка 3 тяговими електродвигунами електровоза ЧС4 (рис. 4) складається 3 двох боковин 1, шворневої балки 2, поперечної балки 3, передньої 4 і задньої 5 кінцевих балок.

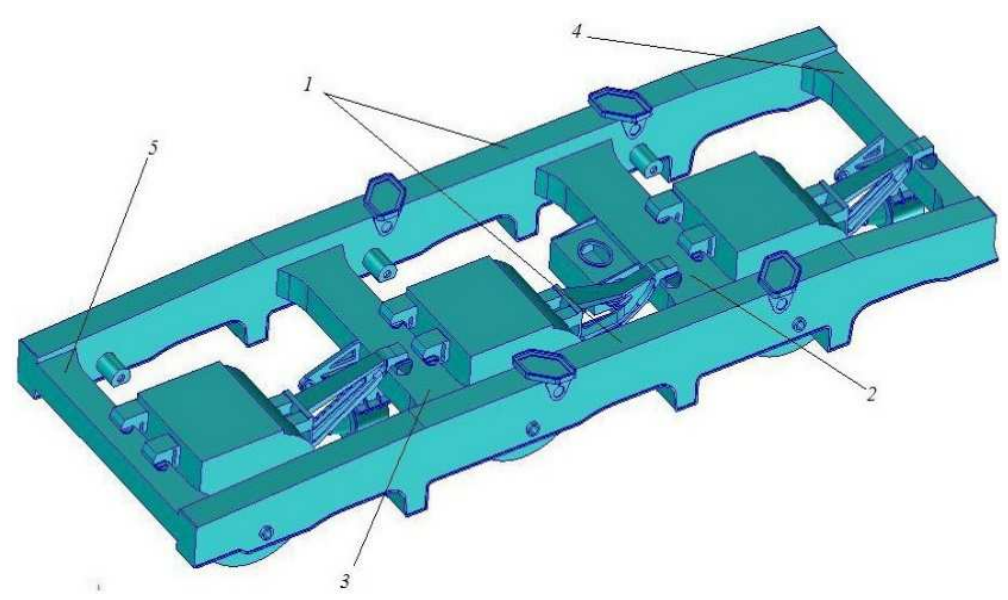

Рис. 4. Тривимірна модель рами візка з тяговими електродвигунами 
Усі болтові з'єднання в моделі замінені на зв'язки площин дотику і вважаються ідеальними.

Для модернізації кронштейнів тягового електродвигуна було розглянуто два варіанти. У першому варіанті передбачалася модернізація за допомогою сайлен-блоків. Але цей варіант виявився нерентабельним, оскільки впровадження таких сайленблоків збільшує вартість конструкції, а також за умовами міцності гуми, тому що іiі жорсткість має приблизно дорівнювати жорсткості металевого кріплення.

У другому випадку розглядалася конструкція, за допомогою якої можна укоротити передній кронштейн двигуна. Для цього було розроблено конструкцію рами візка 3 додатковою накладною балкою. Головною перевагою цієї конструкції на відміну від існуючої, $є$ зручність демонтажу. Під час демонтажу двигуна він знімається разом із додатковою балкою.

Таким чином, для подальшого моделювання було обрано другий спосіб модернізації, оскільки він має кращі характеристики.

Модернізована модель рами візка електровоза ЧС4 (рис. 5) була розроблена так само, як і базова модель, за допомогою програмного продукту SolidWorks. У процесі розроблення нового кріплення тягового електродвигуна модель рами візка залишилася без змін. До конструкції кріплення двигуна були внесені зміни.

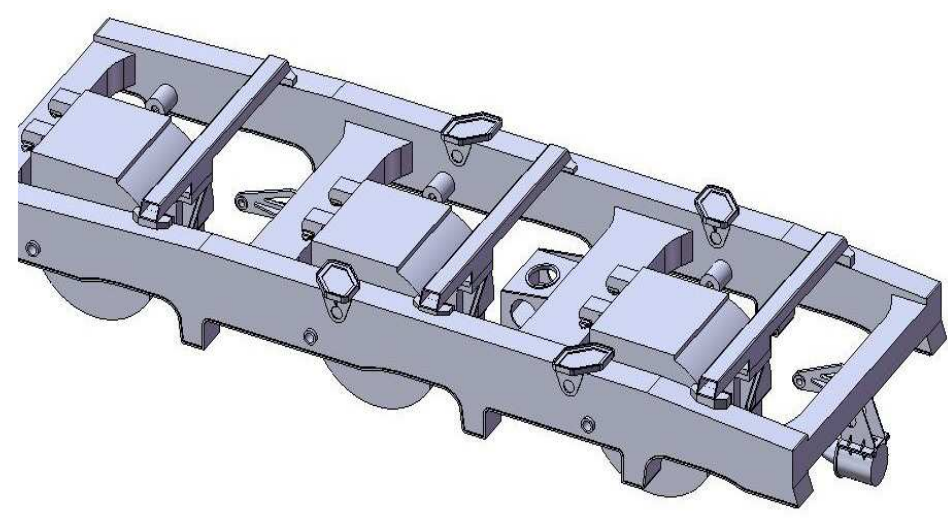

Рис. 5. Модернізована модель рами візка електровоза ЧС4

Двигун з боку, протилежного до колісної пари, спирається двома кронштейнами на поперечну балку (рис. 6, позиція 2). 3 боку осі колісної пари модернізований кронштейн 3 кріпиться за допомогою трьох болтів до додаткової балки 1 , яка спирається на боковини рами візка 4 і скріплена 3 ними болтами.

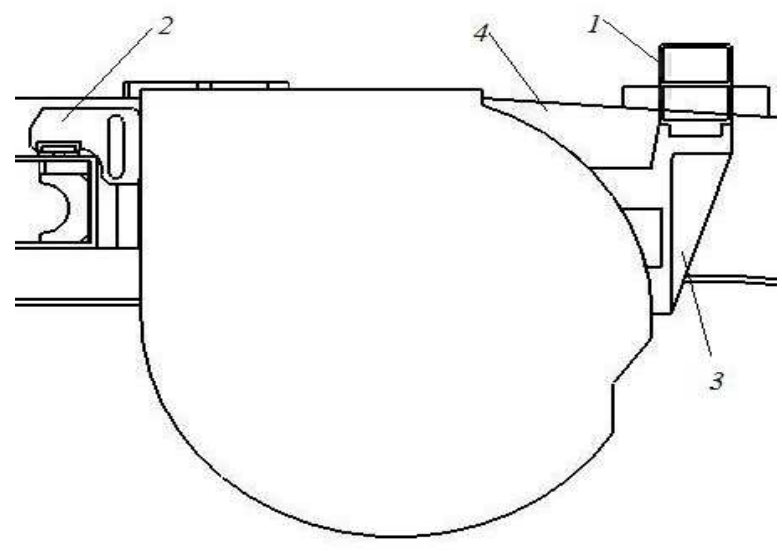

Рис. 6. Модернізоване кріплення тягового двигуна

Додаткову балку (рис. 7) виконано зі зварених листів завтовшки 8 мм, відштампованих у вигляді букви «П». У місцях болтових кріплень до балки приварені сталеві прокладки 1. Для точного встановлення тягового двигуна по відношенню до рами візка і дотримання паралельності осей якоря i колісної пари служать дистанційні прокладки 3. Так само на балці приварений спеціальний уступ 2 для кріплення тягового двигуна.

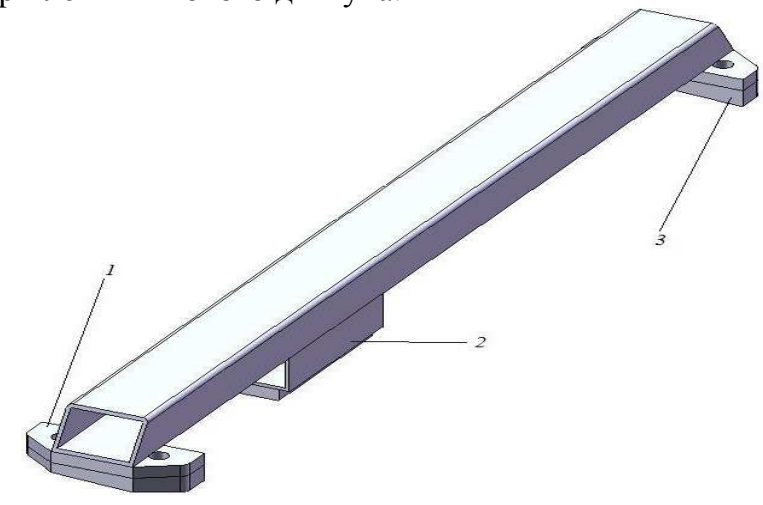

Рис. 7. Додаткова балка

Модернізований кронштейн являє собою литу деталь (рис. 8). Кріплення нового кронштейна до остова тягового електродвигуна залишилося таким самим, як і в існуючому варіанті. Для кріплення до додаткової балки в кронштейні є три отвори діаметром 35 мм. Для виключення можливості деформації в кронштейні зроблено два ребра жорсткості. 
Модернізоване кріплення дасть змогу не тільки зменшити навантаження на болтове з'єднання, але і збільшити жорсткість рами візка за рахунок додаткових балок.
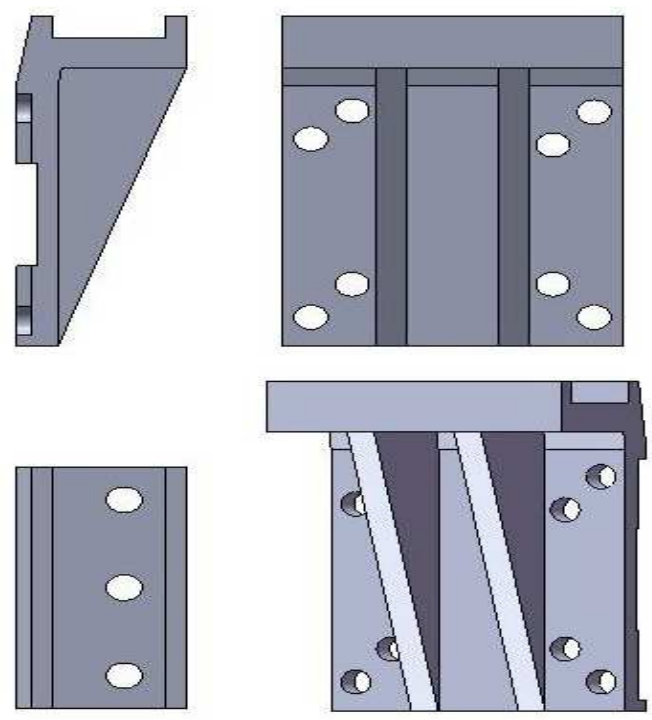

Рис. 8. Модель модернізованого кронштейна

Розрахунки власних частот було проведено за допомогою програмного продукту MSC.Patran [5]. MSC.Patran - інтерактивний програмний продукт 3 відкритою архітектурою, що забезпечує інтеграцію автоматизованих систем проектування, моделювання, аналізу i оцінювання результатів розрахунків. Навантажувальні і граничні умови можуть бути пов'язані як 3 геометричними, так і зі звичайноелементними категоріями. Розвинені засоби візуалізації (зокрема, ізоповерхні) допомагають прискорити i підвищити якість аналізу отриманих результатів розрахунку.

Геометричні моделі для розрахунків були змодельовані в програмі SolidWorks. За результатами розрахунків базової моделі були отримані власні частоти, при яких можуть виникати деформації i вигини в рамі візка.

При власній частоті 20,965 Гц виникає дуже велике навантаження на передні кронштейни переднього i заднього двигунів. Відбувається «закручування рами візка» (рис. 9).

При власній частоті 23,319 Гц найбільше навантаження припадає на передні кронштейни заднього і середнього двигунів. Рама візка працює на вигин (рис. 10).

При власній частоті 31,465 Гц спостерігається незначне навантаження на кронштейни кріплення гальмівних циліндрів (рис. 11).
MSC.Patran

Deform: Default. AI Mode 7: Freq = 20.965. Eigenvectors, Translational.

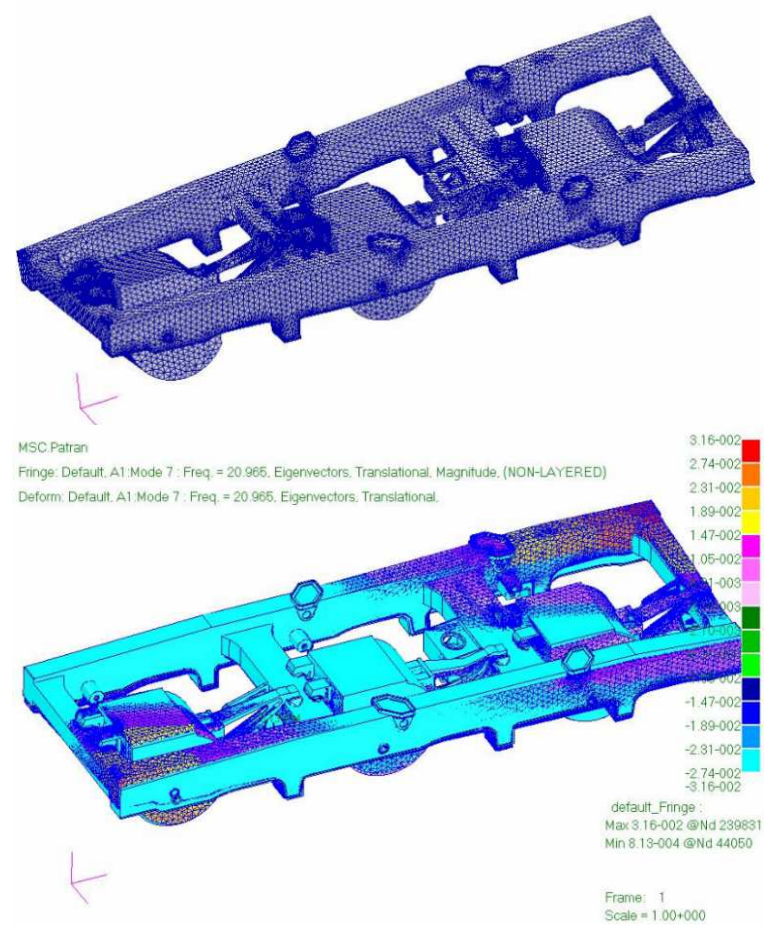

Рис. 9. Розподілення навантаження при власній частоті 20,965 Гц

MSC.Patran

Deform: Default. A1 Mode 8 : Freq. = 23.319. Eigenvectors. Translational.

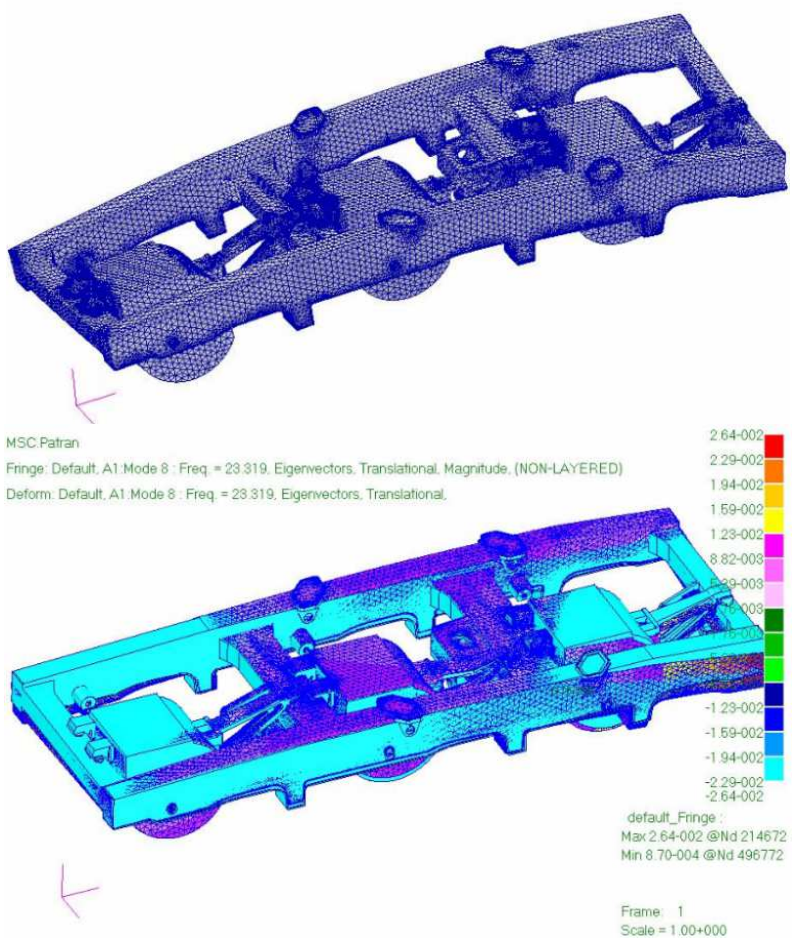

Рис. 10. Розподілення навантаження при власній частоті 23,319 Гц 


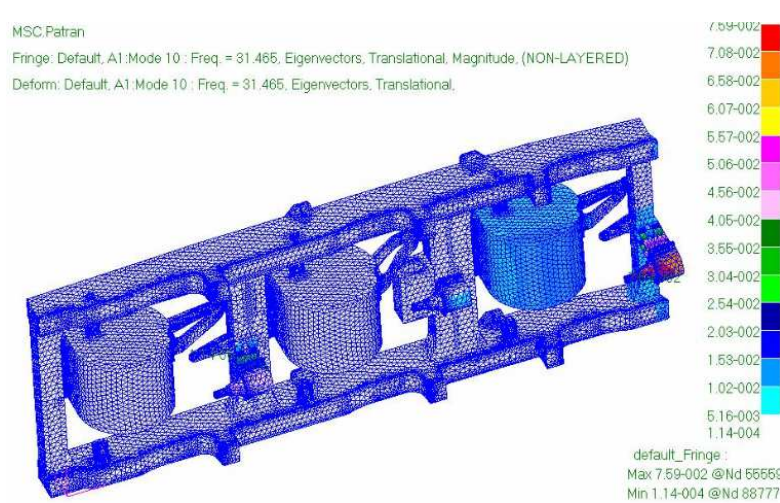

Рис. 11. Розподіл навантаження при власній частоті 31,465 Гц

При аналізі отриманих результатів розрахунку власних частот i форм коливань можна зробити висновок, що найнебезпечнішими для кріплення тягових двигунів є частоти 20,965 Гц і 23,319 Гц.

Так само як і для базової моделі, для нової моделі було розраховано власні частоти, при яких можливі деформації.

При власній частоті 20,565 Гц найбільші коливання відбуваються у переднього кронштейна середнього двигуна. Рама візка працюе на вигин (рис. 12).

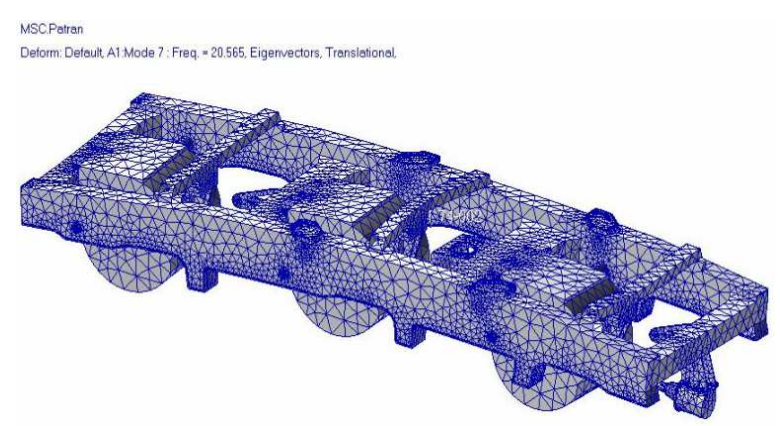

Рис. 12. Коливання рами візка при власній частоті 20,565 Гц

При власній частоті 22,953 Гц відбуваються коливання передньої і задньої додаткових балок, до яких закріплені тягові електродвигуни. Відбувається «закручування рами візка» (рис. 13).

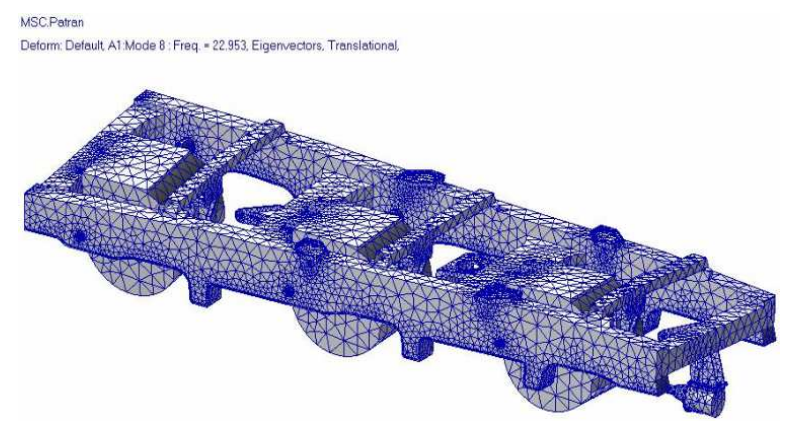

Рис. 13. Коливання рами візка при власній частоті 22,953 Гц
При власній частоті 26,707 Гц відбуваються незначні коливання задньої і середньої додаткових балок (рис. 14).

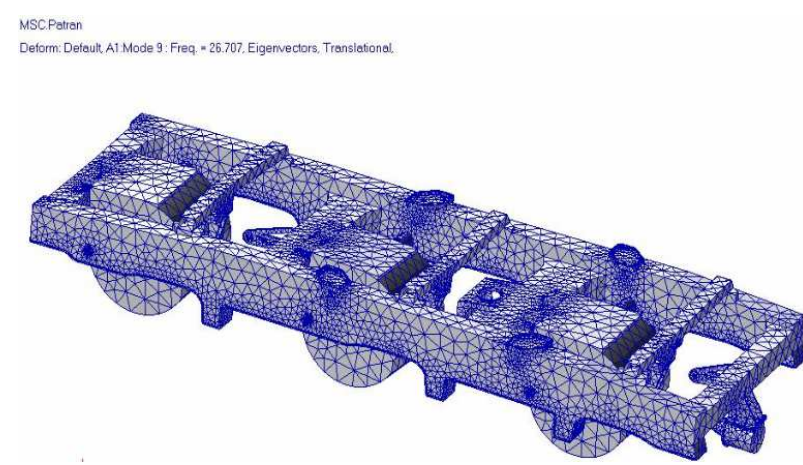

Рис. 14. Коливання рами візка при власній частоті 26,707 Гц

При аналізі отриманих частот і форм коливань можна зробити висновок, що найнебезпечнішими в експлуатації є частоти 20,565 Гц і 22,953 Гц.

Для аналізу власних частот будуємо графік залежності якірної частоти $f_{я \kappa}$ від швидкості $V$ і $2 \cdot f_{я \kappa}$ від швидкості $V$. Для визначення $f_{я \kappa}$ використовуємо формулу:

$$
f_{g \kappa}=\frac{V \cdot 2 \cdot U}{3,6 \cdot D_{\sigma} \cdot 2 \cdot \pi}
$$

де $V$ - швидкість, км/год;

$U$ - передаточне число;

$D_{\sigma}$ - діаметр бандажа.

Зважаючи на те що електровоз чС4 пасажирським, експлуатаційні швидкості перебувають в інтервалі від 80 км/год до 120 км/год. Позначимо цей інтервал на графіку. За допомогою графіка визначимо швидкості при отриманих частотах для базової моделі (рис. 15) і для нової моделі (рис. 16). Червоною лінією на графіках зображено залежності якірної частоти $f_{я \kappa}$ від швидкості $V$, а синьою лінією - залежність $2 \cdot f_{я \kappa}$ від швидкості $V$. Трикутниками на графіках позначено резонансні швидкості при отриманих частотах: червоними від $f_{я \kappa}$, а синіми - від $2 \cdot f_{я \kappa}$.

Аналіз отриманих власних частот і резонансних швидкостей показує, що в новій моделі відбулося зменшення власних частот, а резонансні швидкості змістилися в область експлуатаційних швидкостей. 


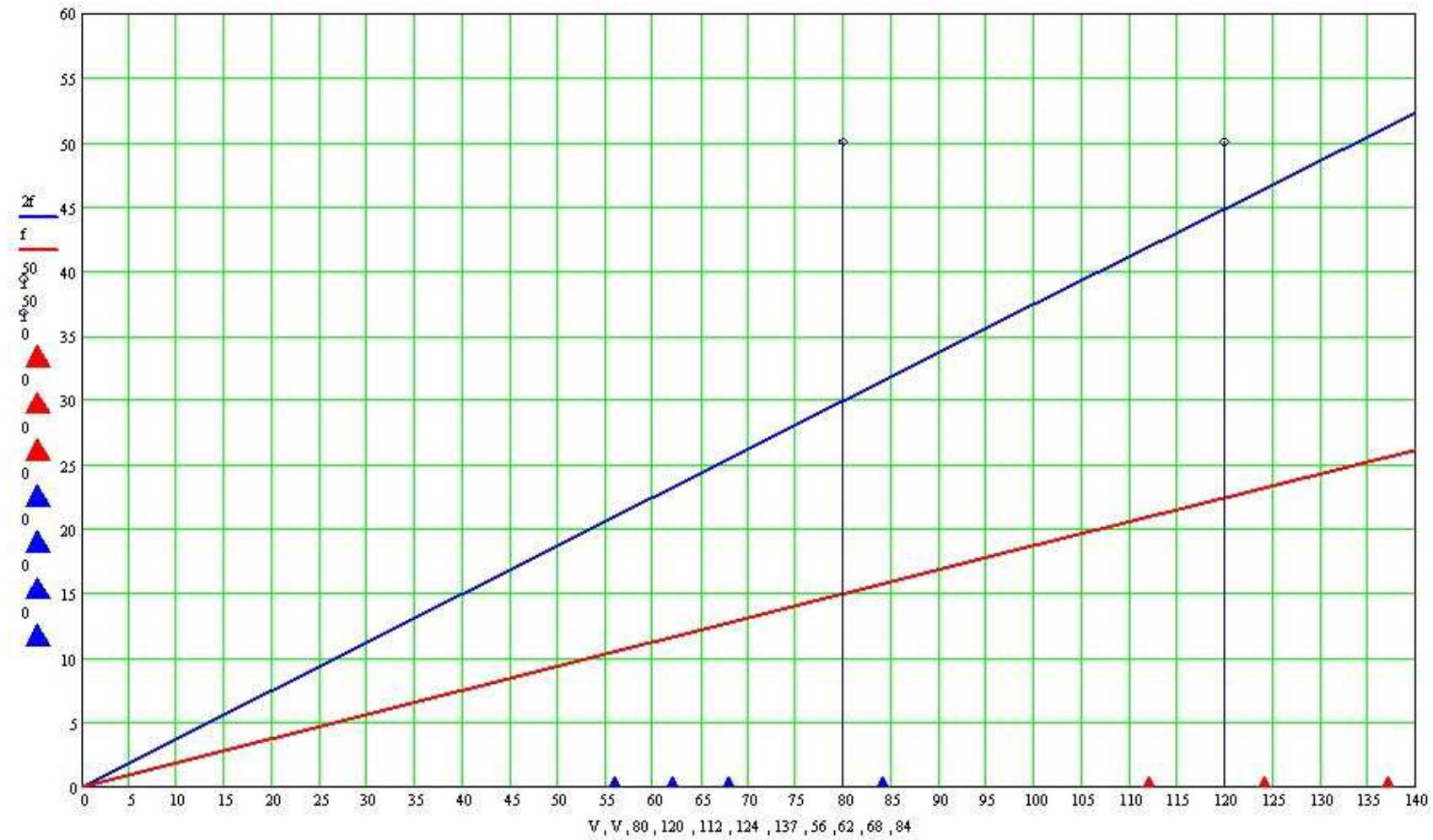

Рис. 15. Графіки залежності $f_{я \kappa}$ і $2 \cdot f_{я \kappa}$ від швидкості $V$ для базової моделі

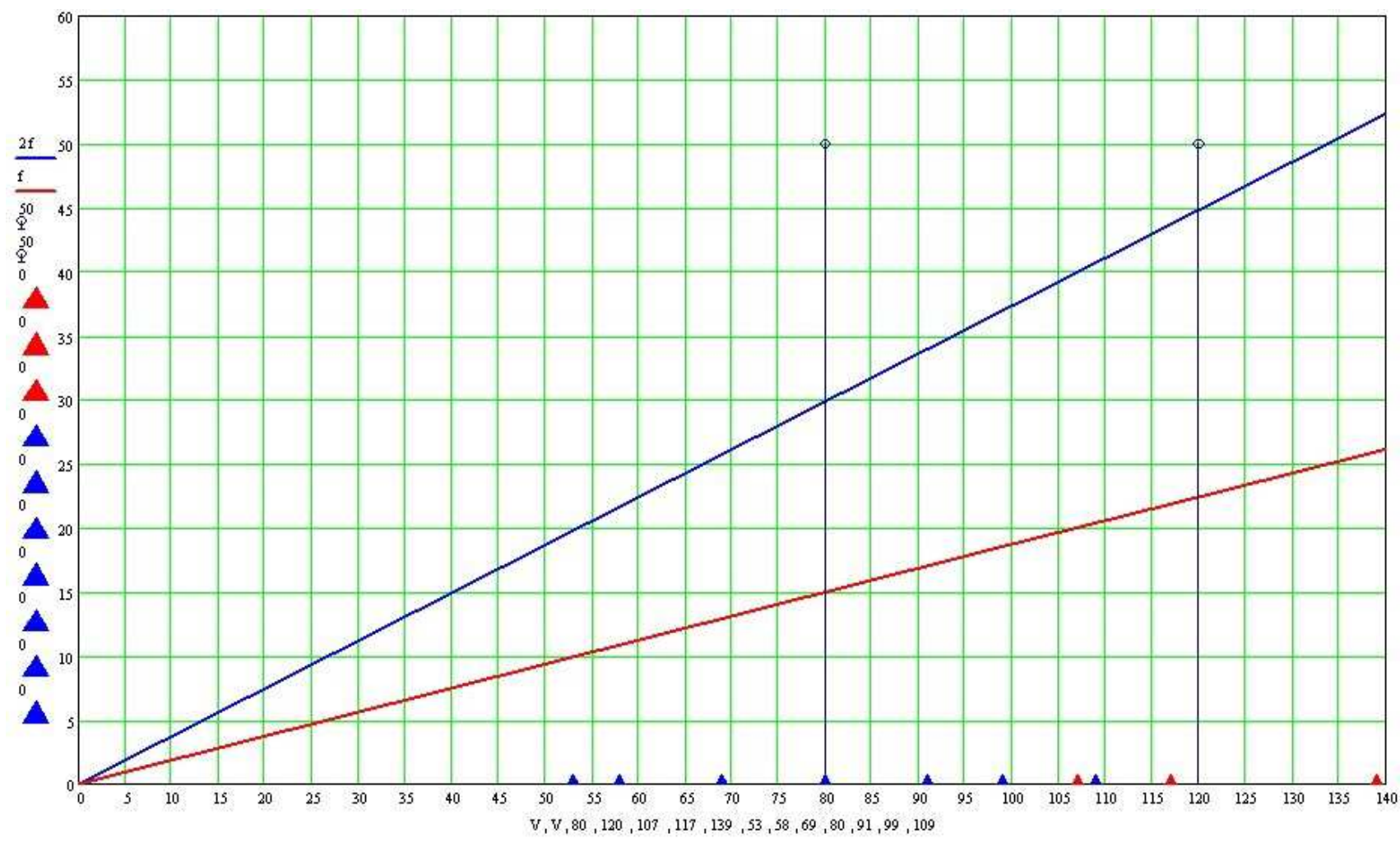

Рис. 16. Графіки залежності $f_{я \kappa}$ i $2 \cdot f_{я \kappa}$ від швидкості $V$ для нової моделі 


Висновки i
використання

Результати проведених досліджень підтвердили, що впровадження запропонованої конструкції рами візка електровоза ЧС4 дасть змогу підвищити динамічні якості їх конструкцій в експлуатації. Розроблена конструкція модернізованого кріплення надасть можливість спростити технологію монтажу тягових двигунів, що значно спрощує їх ремонт. Розроблені в ході досліджень моделі є адекватними, їх доцільно використовувати у відповідних подальших науково-дослідних та дослідно-конструкторських роботах.

Подальший розвиток впровадження запропонованого концепту потребує проведення досліджень особливостей роботи в різних режимах експлуатації, а також проведення подальших стендових та натурних випробувань.

Запропоноване технічне рішення виконання рами візка електровозів ЧС4 доцільно також застосовувати у конструкціях і інших електровозів як вітчизняного, так і закордонного виробництва.

\section{Список використаних джерел}

1. Бирюков, И. В. Механическая часть тягового подвижного состава [Текст] / И. В. Бирюков, А. Н. Савоськин, Г. П. Бурчак. - М. : Транспорт, 1992. -440 c.

2. Блохин, Е. П. Динамика поезда [Текст] / Е. П. Блохин, Л. А. Манашкин. - М. : Транспорт, 1982. $-222 \mathrm{c}$.

3. Галкин, В. Г. Надёжность тягового подвижного состава [Текст]: учеб. пособие для вузов ж.-д. трансп. / В.Г. Галкин, В.П. Парамзин, В. А. Четвергов. - М. : Транспорт, 1981. - 184 с.

4. Каптелкин, В. А. Пассажирские электровозы ЧС4 и ЧС4 ${ }^{\mathrm{T}}$ [Текст] / В. А. Коптелкин, Ю. В. Колесин, И. П. Ильин [и др.]. - 2-е изд., перераб. и доп. - М. : Транспорт, 1975. - 384 с.

5. Применение программного пакета MSC.PatranNastran для построения МКЭ-модели тележки электровоза адекватной реальной [Электронный ресурс]. https://vk.com/doc154519348_438860501?hash= 89c2618a6a7cf26a90\&dl=ae889875745560b66e.

6. Расширенное моделирование деталей. SolidWorks 2010 [Текст] // Dassault Systems Solid Works Corporation, 2009. - $341 \mathrm{c}$.

7. Bogacz, R. On dynamics of systems modeling continuous and periodic guideways [Text] / R. Bogacz, T. Krzyzinski, K. Popp // Archives of Mechanics. 1993. № 45(5). - P. 575-593.

8. Bubnov, V. Theoretical and experimental investigations of strenght properties of cast parts for freight cars bogie with axle load of $245 \mathrm{kN}$ [Text] / V. Bubnov, S. Myamlin, N. Mankevych // Proc. 8th intern. scient. conf. Transbaltica 2013. - Vilnius, 2013. - P. 9-12.
В. П. Нерубацкий, А. А. Плахтий, Д. А. Гордиенко. Разработка трёхмерной модели системы «рама тележки - тяговые электродвигатели» для электровозов ЧС4 с помощью программного продукта SolidWorks. В статье рассмотрены недостатки в существующей модели рамы тележки электровоза ЧС4, связанные с ослаблением кронштейнов крепления, а также технологией монтажа тяговых двигателей. Осуществлена разработка трехмерной модели рамы тележки с двигателями с помощью программного продукта SolidWorks. Проведен расчет собственных частот с помощью программного продукта MSC.Patran.

Ключевые слова: железнодорожный транспорт, электровоз, рама тележки, кронштейны, дополнительная балка, модель.

V. P. Nerubatskyi，O. A. Plakhtiy，D. A. Hordiienko. Development of the three-dimensional model of the «trolley frame-electric motor» system for electric locomotive by the SolidWorks software assistance. At the present stage of development of the railway industry, it is necessary to generate and implement progressive solutions in the design of rolling stock in order to increase the traction rolling stock reliability and efficiency of its use.

The article deals with the drawbacks in the existing model frame truck of the electric locomotive associated with the weakening of the bracket mount, as well as the technology of traction motors. This was developed for this purpose of a three-dimensional trolley frame model with engines using the SolidWorks software has been developed. Carried out frequencies calculation using MSC.Patran software product. The estimation of magnitudes of oscillation amplitudes and eigenfrequencies is carried out. The article is proposed ways of elimination of the revealed problems with the help of introduction of additional beam are offered and suggestions on modernization of the frame frame structure are proposed in order to reduce the load on the traction motor mounting sites and increase the reliability of their work. The introduction design of the modernized fastener electric locomotive allows to increase the dynamic qualities of their structures in operation and allows to simplify the technology of installation of traction engines, which greatly simplifies their repair.

Key words: railway transport, electric locomotive, trolley frame, brackets, additional beam, model.

Надійшла 24.05.2018p. 
Нерубацький Володимир Павлович, к.т.н., старший викладач кафедри електроенергетики, електротехніки та електромеханіки. Украӥнський державний університет залізничного транспорту. E-mail: NVP9@i.ua._ORCID: http://orcid.org/0000-0002-4309$\underline{601 X}$

Плахтій Олександр Андрійович, к.т.н., старший викладач кафедри електроенергетики, електротехніки та електромеханіки. Украӥнський державний університет залізничного транспорту. E-mail: a.plakhtiy1989@gmail.com.

ORCID: http://orcid.org/0000-0002-1535-8991

Гордієнко Денис Анатолійович, магістрант кафедри електроенергетики, електротехніки та електромеханіки. Украйнський державний університет залізничного транспорту. E-mail: denis_gordienko@i.ua.

Нерубацкий Владимир Павлович, к.т.н., стариий преподаватель кафедры электроэнергетики, электротехники $и$ электромеханики. Украинский государственный университет железнодорожного транспорта. E-mail: NVP9@i.ua. ORCID: http://orcid.org/0000-0002-4309-601X

Плахтий Александр Андреевич, к.т.н., стариий преподаватель кафедры электроэнергетики, электротехники и электромеханики. Украинский государственный университет железнодорожного mpaнсnорта. E-mail: a.plakhtiy1989@gmail.com. ORCID: http://orcid.org/0000-0002-1535-8991

Гордиенко Денис Анатольевич, магистрант кафедры электроэнергетики, электротехники $u$ электромеханики. Украинский государственный университет железнодорожного транспорта. E-mail: denis_gordienko@i.ua.

Nerubatskyi Volodymyr Pavlovych, PhD, senior lecturer, chair of electric power industry, electrical engineering and electromechanics. Ukrainian State University of Railway Transport. E-mail: NVP9@i.ua. ORCID: http://orcid.org/0000-0002-4309-601X

Plakhtiy Alexandr Andreevich, PhD, senior lecturer, chair of electric power industry, electrical engineering and electromechanics. Ukrainian State University of Railway Transport. E-mail: a.plakhtiy1989@gmail.com. ORCID: http://orcid.org/0000-0002-1535-8991

Hordiienko Denys Anatolievych, master's degree, chair of electric power industry, electrical engineering and electromechanics. Ukrainian State University of Railway Transport. E-mail: denis_gordienko@i.ua. 